\title{
Transcriptome Analysis of Immune Response Process in Yellow Catfish (Pelteobagrus fulvidraco) During Edwardsiella tarda Exposure
}

\author{
Ying Yang ${ }^{1}$, Junhao Zhou ${ }^{1}$,Pengfei Miao ${ }^{1}$, Jiafang $\mathrm{Xie}^{1}$, Hua Liu ${ }^{1}$, Hui Yu ${ }^{1}, *(\mathbb{D}$ \\ ${ }^{1}$ School of Life Science and Engineering, Foshan University, Foshan 528231, China.
}

\section{How to cite}

Yu, H., Yang, Y., Zhou, J., Miao, P., Xie, J., Liu, Hua., (2022). Transcriptome Analysis of Immune Response Process in Yellow Catfish (Pelteobagrus fulvidraco) during Edwardsiella tarda Exposure. Turkish Journal of Fisheries and Aquatic Sciences, 22(3), TRJFAS20068. http://doi.org/10.4194/TRJFAS20068

\section{Article History}

Received 18 June 2021

Accepted 14 October 2021

First Online 15 October 2021

\section{Corresponding Author}

Tel.: +8675786678587

E-mail: yu71hui@126.com

\section{Keywords}

Edwardsiella tarda

Immune

Signaling pathway

Transcriptome

Yellow catfish

\begin{abstract}
Edwardsiella tarda, the causative agent of ascites disease, is a major fish pathogen and has caused significant economic losses in aquaculture. To decipher the immune response process challenged by $E$. tarda in yellow catfish (Pelteobagrus fulvidraco), the transcriptomic profiles of the spleens infected with bacteria at $6 \mathrm{~h}, 24 \mathrm{~h}$, and $72 \mathrm{~h}$ were obtained using the Illumina sequencing platform. After de novo assembly, a total of 158,124 unigenes were detected. To further investigate the immune-related DEGs, gene ontology (GO) enrichment and KEGG (Kyoto Encyclopedia of Genes and Genomes) pathway analysis were performed. Immune pathways about antigen processing and presentation pathway, complement and coagulation cascades pathway, and apoptosis pathway were combined to discussed in this study. Additionally, 10 immune-related DEGs in these three immune pathways were randomly selected for expression verification by quantitative Real-time PCR (qRT-PCR). The data generated in this study provides a valuable resource for further immune response research and offers efficient strategies against $E$. tarda infection in yellow catfish.
\end{abstract}

\section{Introduction}

Edwardsiella tarda, a typical gram negative bacterium, has been widely reported in important economic fishes, including Paralichthys olivaceus (Bang et al., 1992), Ictalurus punctatus (Meyer \& Bullock, 1973), Scophthalmus maximus (Nougayrede et al., 1994), Pagrus major (Mohanty \& Sahoo, 2007)and Seriola quinqueradiata (Yasunaga et al., 1982). The infection of $E$. tarda can lead to crack-head disease with high morbidity and mortality, threatening the sustainability and productivity of the yellow catfish aquaculture industry. Thus, it is imperative to research the yellow catfish immune response and its related immune genes in response to bacterial infection.
Next generation sequencing (NGS) technology has emerged as a fast and cost-effective way for transcriptome analysis of immune responses against bacterial infections in various aquaculture species. There are several reports of immunological reaction to bacteria using transcriptome analysis in teleost fishes, such as common carp (Cyprinus carpio) (Jiang et al., 2016), Antarctic notothenioid fish (Notothenia coriiceps) (Ahn et al., 2016) and barramundi (Lates calcarifer) (E. Zoccola et al., 2017; Emmanuelle Zoccola et al., 2017). Moreover, we have analyzed the immune response of grass carp (Ctenopharyngodon idella) with transcriptome analysis method (Yang et al., 2016), which suggests it is a reliable technology. There are an 
increasing number of transcriptome analyses of $E$. tarda infection in teleost fish. For example, using transcriptomic techniques, Zan Li et al., (2018) and Bin Sun et al. (2020) analyzed the gene changes in blood and spleen red blood cells of Japanese flounder (Paralichthys olivaceus) infected with E. tarda. Min Cao et al. systematically analyzed circular RNAs (circRNAs), microRNAs (miRNAs) and messenger RNAs (mRNAs) the intestine of black rockfish (Sebastes schlegelii) after infection with E. tarda at different time points $(2,6,12$, and 24 h) (Li et al., 2018; Sun et al., 2020). However, only a few transcriptome studies have focused on yellow catfish infected with E. tarda. Zhu et al. (2017) studied the gene expression profile of yellow catfish resistant to E. tarda infection within $72 \mathrm{~h}$ (Zhu et al., 2017), and Hua Liu et al. (2017) studied mirNa-MRnain gene expression of yellow catfish infected with $E$. tarda at $6 \mathrm{~h}$ (Liu et al., 2021). However, they only studied a certain time point after infection with E. tarda, and the gene expression of the whole immune response period of yellow catfish needs further study.

Therefore, we tested the differentiation of transcriptome of yellow catfish spleen during bacterial pathogen $E$. tarda infection in four time points, to provide new insights into the immune system and defense mechanisms of yellow catfish in response to $E$. tarda. In the present study, the Illumina HiSeq $4000^{\mathrm{TM}}$ platform was employed for transcriptome profiling analysis of the yellow catfish with $E$. tarda infection at 0 h, $6 \mathrm{~h}, 24 \mathrm{~h}$ and $72 \mathrm{~h}$. Subsequently, the differentially expressed genes (DEGs) were found and the immunerelated DEGs were identified via $G O$ and $K E G G$ enrichment analysis. Finally, several differential expressions of selected immune-related genes were verified by qRT-PCR.

\section{Materials and Methods}

\section{Fish and Bacteria}

Healthy juvenile yellow catfish with body weights of $25 \mathrm{~g} \pm 2 \mathrm{~g}$ were kindly provided by Hold-one aquatic breeding center in Foshan (Guangdong, China), and reared at $28{ }^{\circ} \mathrm{C}$ for two weeks in $200 \mathrm{~L}$ aquaria with Eheim biofilters (Liu et al., 2021). The bacterial strain $E$. tarda used in the experiment was isolated from diseased yellow catfish and stored in our laboratory. The bacteria were incubated to mid-logarithmic stage in LuriaBertani (LB) medium at $28{ }^{\circ} \mathrm{C}$, then harvested by centrifugation at $4000 \mathrm{rpm}$ for $5 \mathrm{~min}$, washed twice with phosphate-buffered saline (PBS) and centrifuged again. Bacterial pellets were then resuspended in PBS with concentration of $5 \times 10^{7}$ colony forming units (CFU) $\mathrm{ml}^{-1}$. The fish were randomly divided into two groups (30 fish per group). One group was infected (IG) by an intraperitoneal injection of $0.1 \mathrm{~mL}$ of the $E$. tarda suspension (described above), and the other group was a control (CG), injected with an equal volume of PBS.

\section{Challenge experiments and RNA Preparation}

The spleen samples were collected at $0 \mathrm{~h}, 6 \mathrm{~h}, 24$ $\mathrm{h}$, and $72 \mathrm{~h}$ after infection and immediately stored in liquid nitrogen at $-80{ }^{\circ} \mathrm{C}$ until used for RNA extraction. The total RNA of each sample was extracted using TRIzol Reagent (Invitrogen, USA) following the manufacturer's instructions. The quality and concentration of the total RNA was accurately examined using the Agilent 2100 Bioanalyzer (Agilent Technologies) and the integrity was assessed by electrophoresis on $1 \%$ agarose gel. Three high-quality RNA samples (RNA integrity number (RIN) > 8.0 and Total RNA concentration $>250 \mathrm{ng} / \mu \mathrm{L}$ ) were selected from each group at each time point for the construction of RNA-Seq library construction.

\section{Library Construction and Illumina Sequencing}

After DNase I treatment, mRNA was purified using oligo (dT)25 magnetic beads (Dynabeads ${ }^{\circledR}$ oligo (dT)25, Invitrogen) and subsequently interrupted to short fragments of 150-200 nucleotides using RNA fragmentation reagent (Ambion, USA). Then sequencing libraries were generated using NEBNext ${ }^{\circledR}$ Ultra $^{\text {TM }}$ RNA Library Prep Kit for Illumina (NEB, USA) following manufacturer's recommendations. The cDNAs were checked by Agilent 2100 Bioanalyzer (Agilent, USA) and ABI StepOnePlus Real-Time PCR System ( $A B I$, USA). The mixed DNA libraries were sequenced with Illumina Hiseq $4000^{\text {TM }}$ platform (Chen et al., 2019).

\section{Filtering of Sequencing Reads and De Novo Transcriptome Assembly}

Clean data was obtained by removing low-quality reads and reads contain adapter or ploy- $\mathrm{N}$ from raw data. Preprocessed clean reads were de novo assembled into transcripts using Trinity software package with default values (Manfred G, 2011). Transcripts shorter than $150 \mathrm{bp}$ paried-end read were removed and the remaining sequences were clustered using TGICL software (version v2.1) to reduce redundancy (Pertea et al., 2003). The longest sequence in each gene cluster was preserved and designated as a unigene. Q20, Q30, GC-content and sequence duplication level of the clean reads were calculated.

\section{Unigenes Functional Annotation and Classification}

The assembled unigenes were scanned using the following databases: NCBI nucleotide sequences (NT), NCBI non-redundant rotein (NR), Gene Ontology (GO), Clusters of Orthologous Groups (COG), KEGG and Swissprot. Unigenes with NR annotation were submitted to Blast2GO software (Conesa et al., 2005) to obtain their GO annotations, and were further classified according to 
GO functions using the Web Gene Ontology (WEGO) program (Jia, 2006; Ye et al., 2006). Additionally, these sequences were queried against KOG database for functional classification and aligned to KEGG database for pathway assignment (Moriya et al., 2007; Tatusov et al., 2003). All the genes were searched against the SwissProt, NR, NT, GO, KEGG, and COG databases using the BLASTx algorithm (E-value $<1 E-5$ ).

\section{Differentially Expressed Genes and Enrichment Analysis}

Expression datas from each library were generated by Bowtie2 software (Langmead \& Salzberg, 2012), which were mapped to the transcriptome assembly. To identify DEGs among the libraries, the fragments in kilobase of transcripts per million fragments mapped (FPKM) values were calculated using RSEM (version v1.2.21) (Li \& Dewey, 2011). The false discovery rate (FDR) was used to calculate the threshold $p$-value in multiple tests. Genes with an absolute value log2 Ratio $\geq 2$ and $Q$-value $\leq 0.01$ were defined as DEGs. All identified DEGs were subjected to GO functional enrichment and KEGG pathway analysis.

\section{qRT-PCR of Selected Immune-related Genes Expression}

To examine the reliability of the RNA-Seq results, 10 immune-related DEGs in previously discussed immune pathways were randomly selected for validation using quantitative real-time RT-PCR (qRT$P C R)$. The housekeeping gene $\beta$-actin was used as the reference gene (Liu et al., 2021). Suitable primers were designed using Primer premier 5.0 program (Table 1) and synthesized by Sangon Biotech Co., Ltd (Shanghai, China). QRT-PCR with SYBR Green dye (TaKaRa, Dalian, China) was performed on an ABI PRISM 7500 Fast RealTime PCR System following the manufacturer's protocol. The samples collected at different time points were pooled, and used for qPCR analysis. Each group was created by combining equal amounts of RNA from three replicate pools (three individual fish per pool). The RNA samples selected for qRT-PCR assay were the same as those used for the transcriptomic sequencing. All reactions were performed in triplicates. The qRT-PCR reaction system $(25 \mu \mathrm{l})$ consisted of $12.5 \mu \mathrm{L}$ of $2 \times$ SYBR qPCR Mix, $1 \mu \mathrm{L}$ of forward and reverse primers, $1 \mu \mathrm{L}$ of CDNA, and $10.5 \mu \mathrm{L}$ of RNase-free $\mathrm{H}_{2} \mathrm{O}$. The qRT-PCR procedure was as follows: $95{ }^{\circ} \mathrm{C}$ for $5 \mathrm{~min}$, followed by 40 cycles of $95^{\circ} \mathrm{C}$ for $10 \mathrm{~s}$, and $60{ }^{\circ} \mathrm{C}$ for $1 \mathrm{~min}$. The melting curves of each reaction from $60^{\circ} \mathrm{C}$ to $95^{\circ} \mathrm{C}$ were analyzed after PCR amplification. The amplification efficiency of each pair of primers ranged from 90(\%) to $100(\%)$. The relative expression ratio of the target genes versus $\beta$-actin gene was calculated using $2^{-\triangle \Delta C T}$ method and all data were given in terms of relative mRNA expression (Livak \& Schmittgen, 2001). The threshold for significance was set at $P<0.05$, and high significance was set at $P<0.01$.

\section{Results}

\section{Sequencing and De Novo Assembly}

The yellow catfish infected with E. tarda showed clinical signs including 'hole in the head' lesion, hemorrhages in the lower jaw and at the base of fins, abdominal distension, and yellowish fluid in the intestine. After filtering to remove low-quality sequences, a total of $569,584,794$ clean reads were generated with a higher Q20(\%) and Q30(\%) (Table 2) with equal GC content. A total of 158,124 unigenes were obtained by de novo assembly. The length of assembled unigenes ranged from $200 \mathrm{bp}$ to 27,705 bp, with an average length of $1,166.50 \mathrm{bp}$ and an N50 of 2,408 bp (Table 3). Raw sequencing reads data has been submitted to Sequence Read Archive in NCBI, SRA accession nos. SRP155088.

\section{Annotation of Assembled Unigenes}

In order to obtain comprehensive genes function information, 158,124 unigenes were annotated using six databases including NT, NR, GO, COG, KOG and SwissPort.

Results showed that 80,820 unigenes, that accounted for almost $51.11 \%$ of the total number of unigenes, were annotated in at least one database. Of these, 62,786 (39.71\%), 66,702 (42.18\%), 36,344 (22.98\%), $24,213(15.31 \%), 55,594$ (35.16\%) and 58,022 (36.70\%) unigenes were annotated by NT, NR, GO, COG, KEGG and Swiss-Prot databases, respectively (Figure 1).

\section{Differential Expression Analysis}

The differences in gene expression after the E. tarda infection were assessed to explore the transcriptomic response of yellow catfish. The numbers of total DEGs in spleen at 6 h, 24 h, and $72 \mathrm{~h}$ were 6,866 (4,005 upregulated and 2,861 down-regulated genes), 3,028 (2,245 up-regulated and 783 down-regulated genes), and 737 (549 up-regulated and 188 down-regulated genes), respectively (Figure. 2).

\section{GO and KEGG Enrichment Analysis of Differently Expressed Genes}

GO is a standardized system for categorizing genes and gene products across species. The results of the GO enrichment analysis of differentially expressed genes were classified into three categories: biological process, cellular component and molecular function. The significant GO terms in these three categories and DEGs of them at each time were showed in Figure 3. In order to better understand the pathway, DEGs were compared to the KEGG database for pathway enrichment. At 6 h, 4,396 of 6,866 DEGs were annotated to 301 signaling pathways in KEGG. At $24 \mathrm{~h}, 2,014$ of 3,028 DEGs were annotated to 287 signaling pathways 
Table 1. List of primers used for qRT-PCR validation of the RNA-Seq data.

\begin{tabular}{|c|c|c|c|c|c|c|}
\hline Gene & Forward primer $\left(5^{\prime}-3^{\prime}\right)$ & $\operatorname{TM}\left({ }^{\circ} \mathrm{C}\right)$ & Reverse primer $\left(5^{\prime}-3^{\prime}\right)$ & $\mathrm{TM}\left({ }^{\circ} \mathrm{C}\right)$ & $\begin{array}{l}\text { Amplicon } \\
\text { length (bp) }\end{array}$ & $\begin{array}{l}\text { Accession } \\
\text { Number }\end{array}$ \\
\hline$\beta$-actin & ATTGCCGCACTGGTTGTT & 58.15 & CCTGTTGGCTTTAGGGTT & 54.32 & 336 & M25013.1 \\
\hline MHC I & ACTTGGTCAGGTGGATGGAT & 58.33 & CTCACAGCCGTACATCACCT & 59.47 & 235 & M25013.1 \\
\hline $\mathrm{MHC} \mathrm{II}$ & СTCCTCCTGTCCGTATCCAC & 58.97 & ACACCACAAAACACAGACGG & 58.91 & 244 & M25013.1 \\
\hline HSP9O & GCAAAGGTCCGCATTGAGAA & 59.12 & ACCCACAGACCCGAATCAAT & 59.01 & 230 & M25013.1 \\
\hline C6 & GCTGTGCAAAACCTCTTCCA & 58.97 & АTCTCTCCAGGTTTGCAGCT & 59.01 & 217 & M25013.1 \\
\hline $\mathrm{C7}$ & CTATGCCCTGTATGCCAAAT & 55.54 & ССTCCAGTGCCСTCTTCA & 58.19 & 143 & M25013.1 \\
\hline F3 & GGATGTTTTCGGGGATGAGC & 58.97 & GTTTGCAGCACGTGAAGGTA & 59.06 & 169 & M25013.1 \\
\hline F7 & GAGCTGAAGACGGGGAATCT & 59.17 & AATCGATTGCTCACAGTGGC & 58.91 & 240 & M25013.1 \\
\hline CASP3 & TGACTTGCTGTGGTCCTCTT & 58.87 & AACGGAACTGATGTTGATGC & 56.72 & 141 & M25013.1 \\
\hline CASP6 & AACCACAAGAGACGGGGAAT & 58.94 & AAAAGACGCAGACAAGGCAG & 59.05 & 238 & M25013.1 \\
\hline TNF $\alpha$ & GCAACTGGGCTCAAGCTTAC & 59.48 & GGTCCTGGTTCACTCTCCAA & 58.94 & 2617 & M25013.1 \\
\hline
\end{tabular}

Table 2. Summary of sequencing reads after filtering.

\begin{tabular}{lcccccc}
\hline Type & Total Clean Reads & Total Clean Bases & GC(\%) & Q20(\%) & Q30(\%) & $\begin{array}{c}\text { Total Clean Reads } \\
\text { Ratio(\%) }\end{array}$ \\
\hline PF_Dm1(0 h) & 45984780 & 6897717000 & 46.26 & 92.97 & 84.45 & 99.55 \\
PF_Dm2(0 h) & 52545358 & 7881803700 & 46.8 & 94.99 & 88.66 & 99.31 \\
PF_Dm3(0 h) & 45687904 & 6853185600 & 46.35 & 94.95 & 88.54 & 99.15 \\
PF_6m1(6 h) & 48385674 & 7257851100 & 46.02 & 94.84 & 88.61 & 99.36 \\
PF_6m2(6 h) & 43708058 & 6556208700 & 45.84 & 94.22 & 87.37 & 99.31 \\
PF_6m3(6 h) & 44524184 & 6678627600 & 46.16 & 94.27 & 87.32 & 99.26 \\
PF_24m1(24 h) & 46556698 & 6983504700 & 46.19 & 95.04 & 88.91 & 99.14 \\
PF_24m2(24 h) & 44453980 & 6668097000 & 46.05 & 94.76 & 88.17 & 99.15 \\
PF_24m3(24 h) & 44716168 & 6707425200 & 45.91 & 94.25 & 87.27 & 99.15 \\
PF_72m1(72 h) & 53210664 & 7981599600 & 45.91 & 94.02 & 86.8 & 99.39 \\
PF_72m2(72 h) & 56036240 & 8405436000 & 46.78 & 91.97 & 82.76 & 99.75 \\
PF_72m3(72 h) & 43775086 & 6566262900 & 46.18 & 94.8 & 87.91 & 99.7 \\
\hline
\end{tabular}

Table 3. Statistics of assembled unigenes.

\begin{tabular}{lcccccc}
\hline Sample & Total Number (bp) & $\begin{array}{c}\text { Min_Length } \\
(\mathrm{bp})\end{array}$ & $\begin{array}{c}\text { Max_length } \\
(\mathrm{bp})\end{array}$ & $\begin{array}{c}\text { Mean_Length } \\
(\mathrm{bp})\end{array}$ & N50 length (bp) & GC(\%) \\
\hline All & 158124 & 200 & 27705 & 1166.50 & 2408 & 43.8 \\
\hline
\end{tabular}

in KEGG. At 72 h, 542 of 737 DEGs were annotated to 247 signaling pathways in KEGG. The top30 most enriched pathway terms and DEGs of them at $6 \mathrm{~h}, 24 \mathrm{~h}$, and $72 \mathrm{~h}$ were showed in Figure 4 and Figure 3, respectively. Among these pathways, 16 pathways associated with immune system were identified.

\section{qRT-PCR Validation for RNA-Seq Data}

We tested the expression of 10 immune-related DEGs at three time points using $q R T-P C R$ to validate the DEGs identified by RNA-Seq. The qRT-PCR analysis demonstrated a single product for all validated DEGs. Fold changes at each time point of qRT-PCR were compared with the RNA-Seq expression profiles. The selected genes are involved in the immune signaling pathway, including antigen processing and presentation pathway (major histocompatibility complex, class I (MHC I ), major histocompatibility complex, class II (MHC II ), heat shock protein 90(HSP90) ), complement and coagulation cascades pathway (complement component 6 (C6), complement component 7 (C7), coagulation factor III (F3), coagulation factor VII (F7) ), and apoptosis pathway (caspase 3 (CASP3), caspase 6 (CASP6), tumor necrosis factor alpha (TNF $\alpha)$ ). As showed in Figure 5, all trends of qRT-PCR results were consistent with the RNA-Seq results, and they displayed trend patterns identical with those of DEGs in both methods.

\section{Discussion}

In this research, transcriptome profiling of yellow catfish was used to gain insights into the molecular mechanisms underlying host responses to $E$. tarda. We focused on screening immune-related genes and pathways. The sequencing results showed that DEGs had a linear downward trend over time. Most DEGs appeared at $6 \mathrm{~h}$, indicating the immune response was activated at the early stage. Taking the advantages of GO annotation and KEGG pathway classification, the regulations of selected immune related genes in antigen processing and presentation pathway, complement and coagulation cascades pathway, and apoptosis pathway were combined to analyzed in detail (Table 4). 


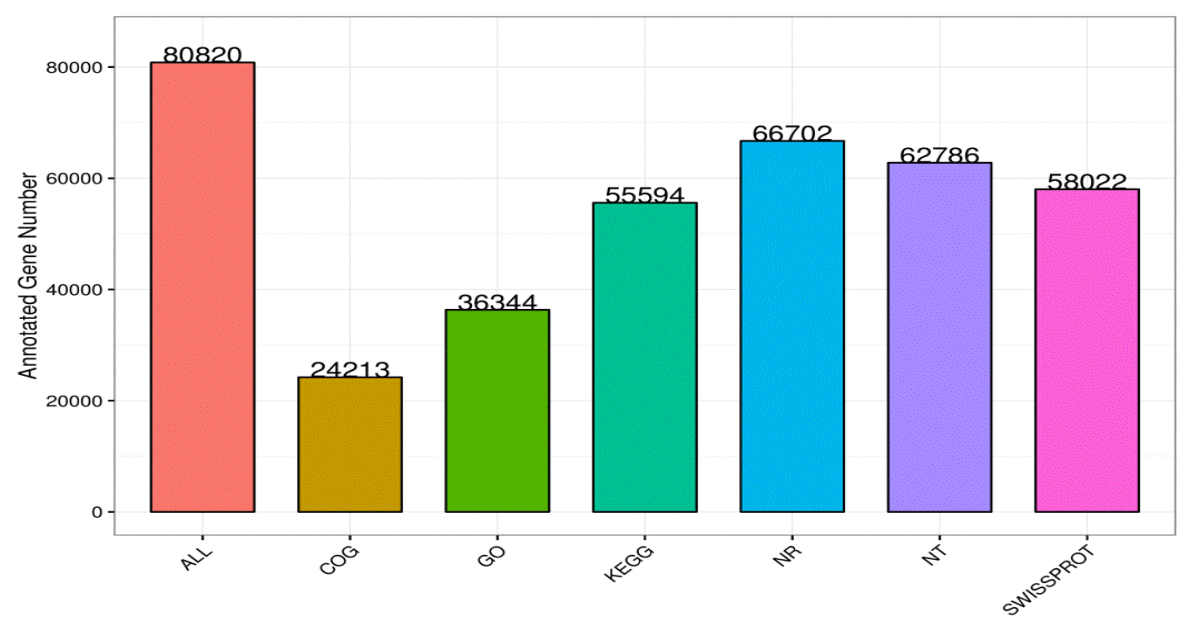

Figure 1. The annotated gene number in different databases. The $x$-axis represents the union of all data and the $y$-axis represents the number of unigenes on the corresponding database annotation.

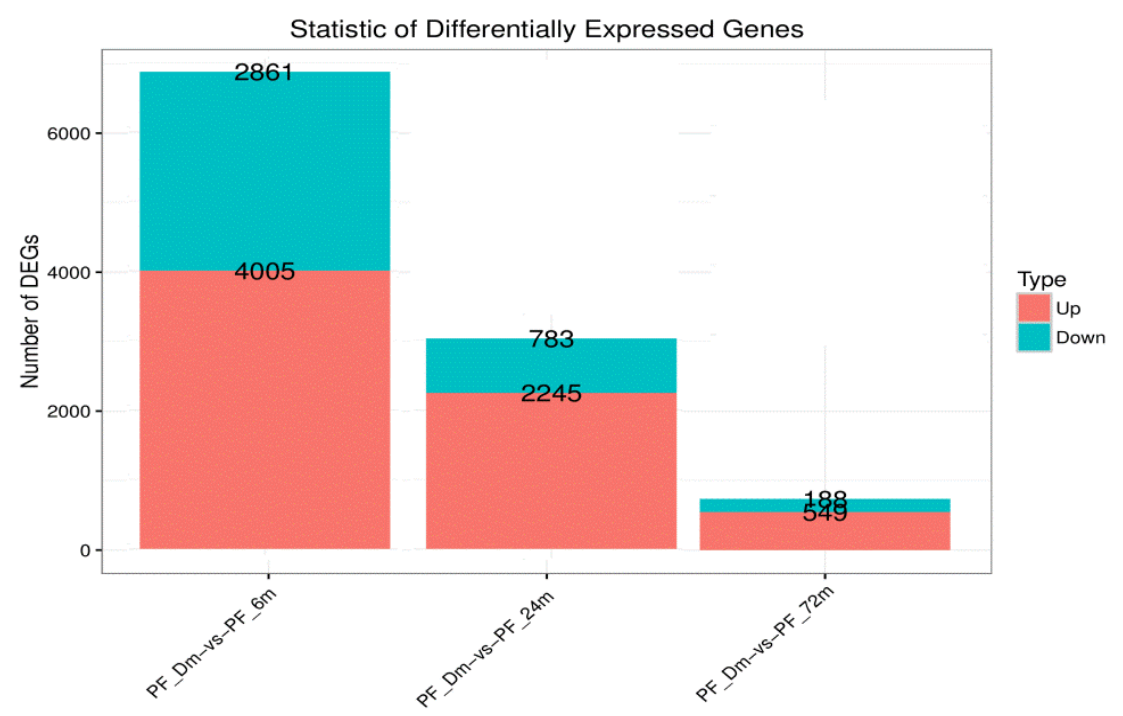

Figure .2. The number of up-regulated and down-regulated DEGs compared between different time points under $E$. tarda challenge at $0 \mathrm{~h}\left(\mathrm{PF} \_\right.$Dm $), 6 \mathrm{~h}\left(\mathrm{PF} \_6 \mathrm{~m}\right), 24 \mathrm{~h}\left(\mathrm{PF} \_24 \mathrm{~m}\right)$, and $72 \mathrm{~h}\left(\mathrm{PF} \_72 \mathrm{~m}\right)$.

\section{Apoptosis}

Apoptosis, also called programmed cell death, plays a considerable role in immune response. In the present study, the caspase pathway is an important pathway involved in E. tarda-triggered apoptosis. Caspase activity has been thought to be a useful marker for assaying stress-induced apoptosis in the early immune stages of fishes, during which caspase- 3 is confirmed as a key executor to be activated down-stream in apoptosis pathways (Liu et al., 2007). Generally speaking, there are two pathways of caspase activation involved in apoptosis. The first one is initiated by the stressmediated release of cytochrome $c$ from the mitochondria, which promotes downstream effector caspase-3 activation through formation of the cytochrome c/Apaf-1/caspase-9-containing apoptosome complex then leading to the characteristic phenotype of apoptosis (S. Fulda, 2009). In the second pathway, stimulation of Fas, tumour necrosis factor receptor (TNFR) or TNF-related apoptosis-inducing ligand receptors (TRAILR) results in activation of the initiator caspase-8 (Simone Fulda, 2009). In our study, except for caspase-9, Fas, tumor necrosis factor superfamily (TNF $\alpha)$, TRAILR, caspase 3, caspase 6, caspase 7 , and caspase 8 were DEGs, indicating the second caspase-dependent apoptotic pathway may contribute greatly to the $E$. tarda-induced apoptosis in the early immune response of yellow catfish.

Current studies have shown that, by inhibiting apoptosis, microbial pathogens can replicate in cells and avoid inflammatory and antimicrobial effects outside the host cell (Faherty \& Maurelli, 2008; Raymond et al., 2013). Ze-Jun Zhou et al. also suggested that Edwardsiella tarda takes the inhibition of apoptosis as its cellular survival strategy, but the specific mechanism of action needs to be further studied (Zhou \& Sun, 2016). Some lipopolysaccharides (LPS) in the cell wall of 


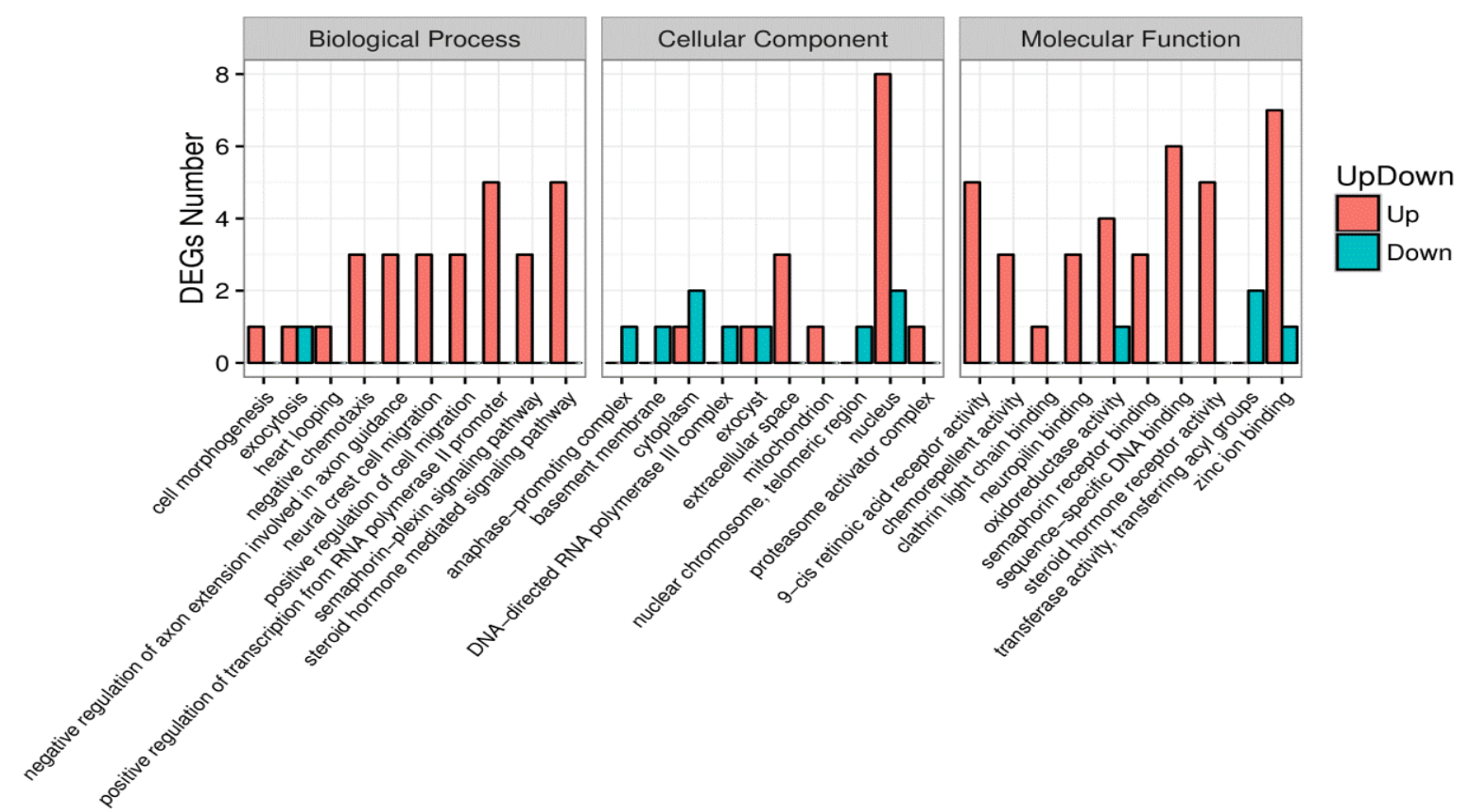

Figure 3. GO enrichment analysis of differentially expressed genes at $6 \mathrm{~h}$ among three categories: biological process, cellular component and molecular function. The $x$-axis is gene functional classification of $\mathrm{GO}, \mathrm{y}$-axis is the corresponding number of upregulated and down-regulated genes.

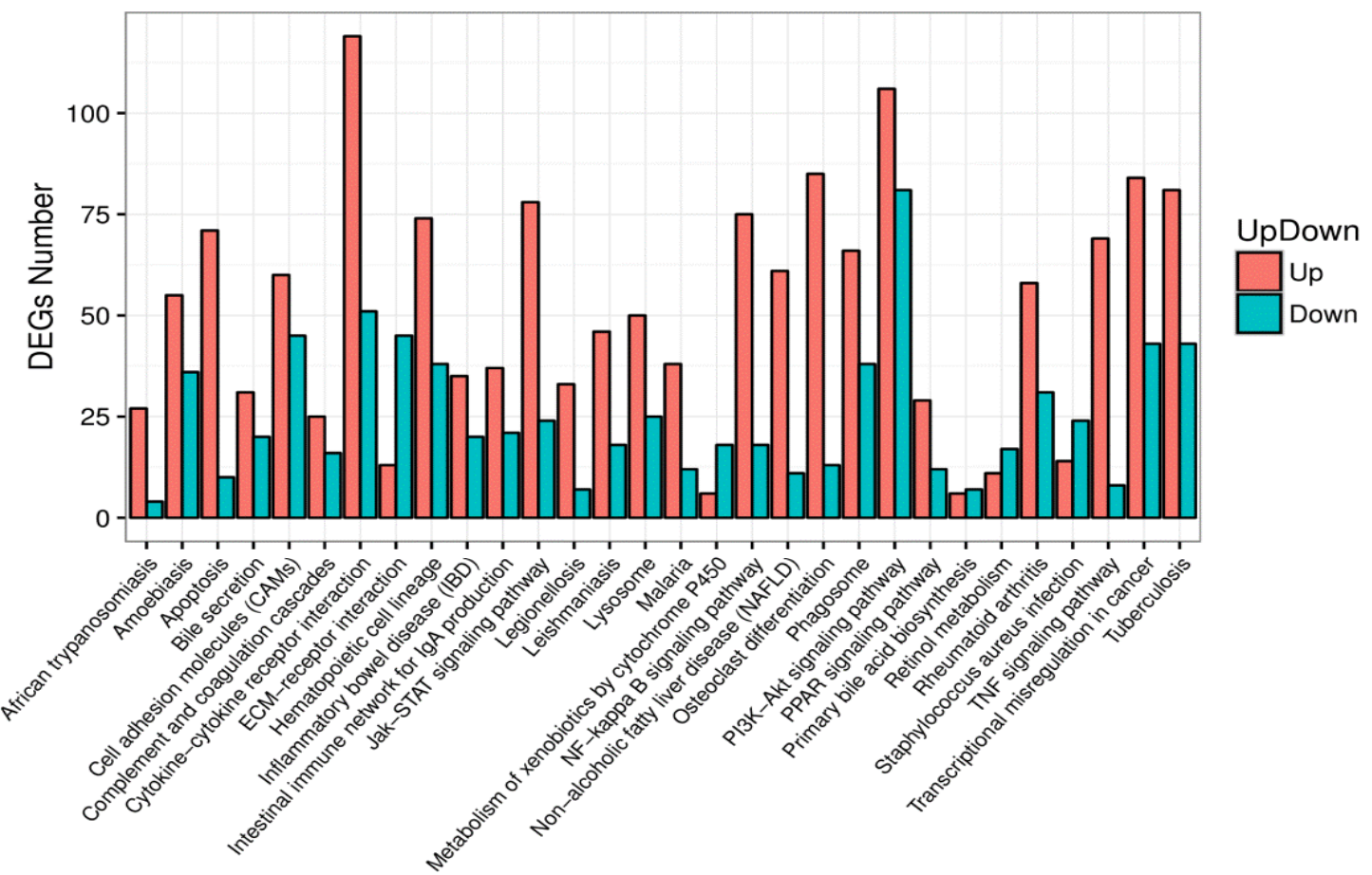

Figure 4. The top30 most enriched KEGG pathways at $6 \mathrm{~h}$. The $\mathrm{x}$-axis is KEGG pathway classification and $\mathrm{y}$-axis is the corresponding number of up-regulated and down-regulated genes.

Gram-negative bacteria can inhibit apoptosis by activating the nuclear factor- $\mathrm{KB}$ (NF-KB) during infection (Pålsson-McDermott \& O'Neill, 2004). NF-KB is mainly activated through two pathways: the canonical and noncanonical NF-KB signaling pathways (Sun, 2017). In the canonical pathway, the NF-kB pathway responds to stimulation from various immune receptors, such as interleukin 1 receptor type I (IL-1R) and tumor necrosis factor receptor superfamily member $1 \mathrm{~A}$ (TNF-R1), which activate inhibitor of nuclear factor kappa-B kinase subunit alpha (IKK), phosphorylate NF-kappa-B inhibitor alpha $(I \kappa B \alpha)$ and promote its ubiquitination, which ultimately activates NF-KB to enter the nucleus for transcriptional regulation (Vallabhapurapu \& Karin, 
2009). The non-canonical pathways rely on IKK homodimer and NF-KB induced kinase (NIK) (Dejardin, 2006; Senftleben et al., 2001).

In this study, interleukin 1 alpha (IL-1) and TNF $\alpha$, as the signature pro-inflammatory cytokines, were significantly upregulated at $6 \mathrm{~h}$, indicating that the inflammatory response was triggered at the early stage of infection. Proinflammatory cytokines IL-1R and TNF$\mathrm{R} 1$ were significantly up-regulated at $6 \mathrm{~h}$, while IKK, IKB $\alpha$ and NF-KB were significantly up-regulated, and NIK did not show any significant differences. At 6h, proinflammatory cytokines IL-1R and TNF-R1 were significantly up-regulated, IKK, IKB $\alpha$ and NF-KB were significantly up-regulated, while NIK did not change significantly. The present results suggest that the Edwardsiella may activate NF-KB through the canonical pathway. Then the activated NF-KB enters the nucleus and binds to the associated genetic elements, regulating the expression of a wide range of anti-apoptotic molecules such as $\mathrm{Bcl}$-2-like 1 (Bcl-XL), apoptosis regulator $\mathrm{BAX}$ (Bax) (Chen \& Chen, 2013; DiDonato et al., 1997). In mammals, NF-kB can regulate the antiapoptotic molecules Bcl-XL to inhibit cell apoptosis. And Guoqin Qi et al. have preliminarily confirmed that Bcl-XL

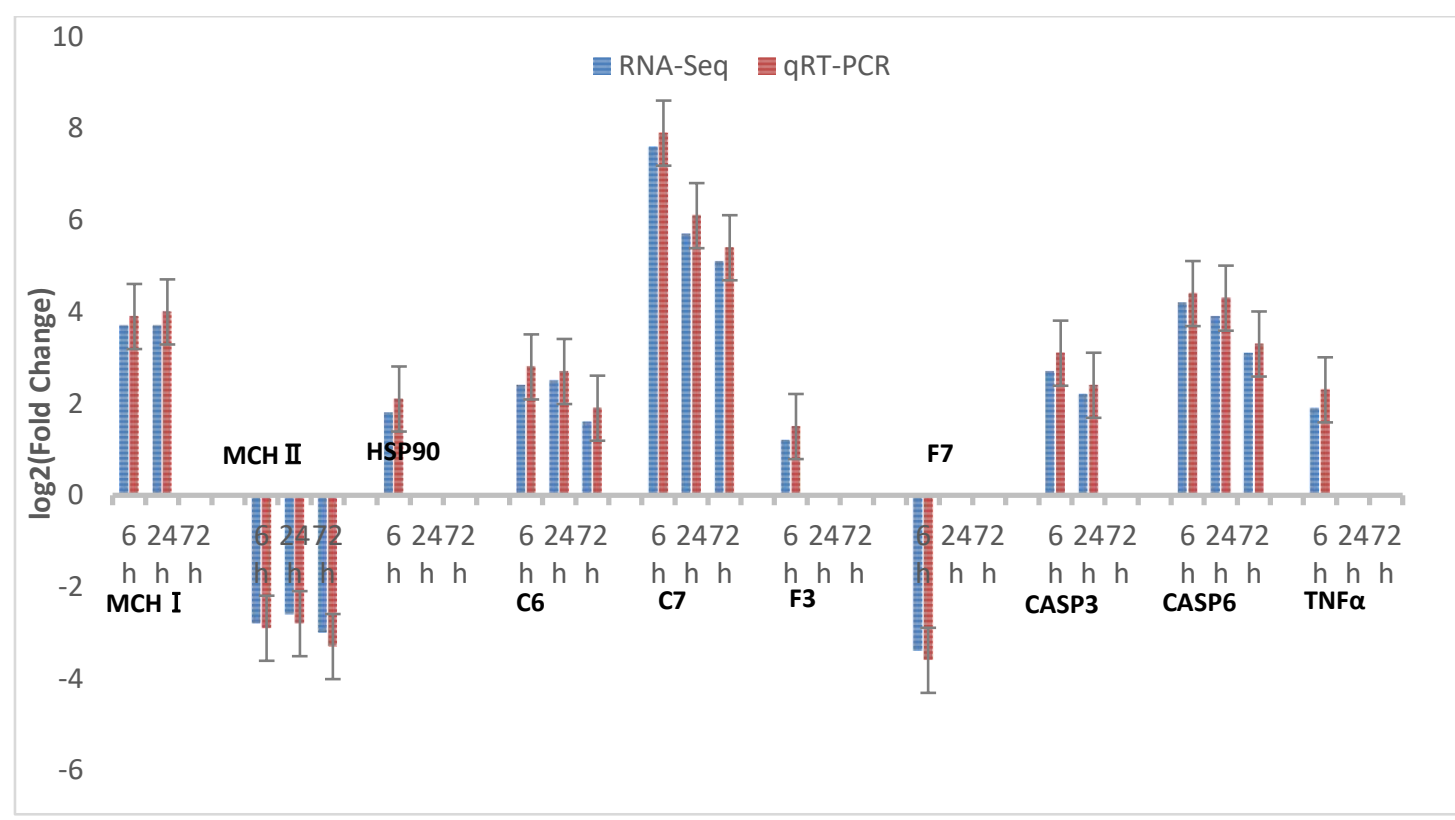

Figure 5. Comparison of the expressions of RNA-Seq and qRT-PCR results at each time point. The transcript expression levels of the selected genes were each normalized to that of the $\beta$-actin gene.

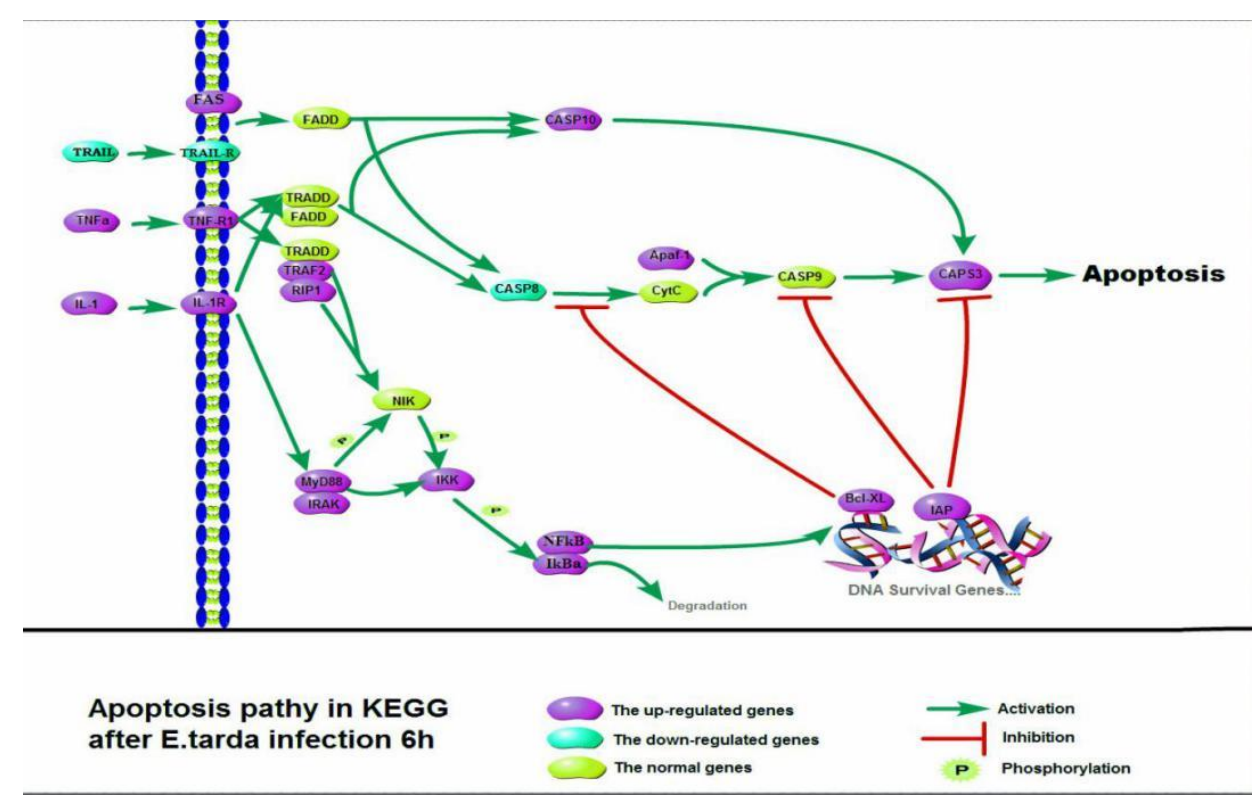

Figure 6. Pathway diagram of KEGG cell apoptosis. Apoptosis pathway $6 \mathrm{~h}$ after E.tarda infection. 
of grass carp is involved in the apoptotic signaling pathway of NF-KB (Qi et al., 2020). In our study, both NF$\mathrm{KB}$ and $\mathrm{BCl}-\mathrm{XL}$ were up-regulated at $6 \mathrm{~h}$. Therefore, we propose that Edwardsiella tardiness intervenes cell apoptosis of yellow catfish through NF-KB pathway in the initial immune stage.

Moreover, the activities of the caspase were rapidly decreased at $72 \mathrm{~h}$ upon E. tarda treament. Combined with our previous experiment (Yang et al., 2019), which showed the spleen of yellow catfish was severely damaged at $72 \mathrm{~h}$ after being injected with $E$. tarda. Thus, we may speculate that the spleen is an important potential target organ for E. tarda in yellow catfish and E. tarda-induced apoptosis may result in depressing immune cell, eventually disturbing the immune response of yellow catfish (Table 4 and Figure 6).

\section{Complement and Coagulation Cascades}

The complement system is the bridge between innate and adaptive immune responses against pathogen invasion. The three complement pathways (classical, lectin, and alternative pathways) converge to the lytic pathway, opsonization or direct killing of pathogens. In our results, complement component $(3 \mathrm{~b} / 4 \mathrm{~b})$ receptor 1 (C1R), C6 and C7 showed up-regulation at $6 \mathrm{~h}$ and $24 \mathrm{~h}$, indicating the activation of classical pathway. At $24 \mathrm{~h}$ and $72 \mathrm{~h}, \mathrm{C} 3$ was up-regulated, indicating the alternative pathway was activated. The differential genes expression analyses showed that upon exposure to $E$. tarda complement factor responses were higher at $24 \mathrm{~h}$ compared to $6 \mathrm{~h}$ and $72 \mathrm{~h}$. This result suggested that the complement system tagged and killed invading microbes and promoted inflammatory responses mainly at $24 \mathrm{~h}$. In summary, our results suggest that the complement system recognizes the pathogenic bacterium and activates subunits of the membrane attack complex (MAC), which is a prerequisite for formation of a MAC complex at the surface of the microbe and thereafter cell lysis (Markiewski et al., 2007; Nakao et al., 2011). Moreover, complement receptors involved in phagocytosis, degranulation and chemotaxis such as C6, C7, C5a anaphylatoxin chemotactic (C5R1) and CR1 were upregulated, which are related to the need to recruit host phagocytic cells for clearance of the bacterium. On the other hand, the coagulation pathway is a complex process to stop blood loss from injury through a series of sequentially activated serine kinases (Palta et al., 2014). In our study, several factors, such as tissue factor pathway inhibitor (TFPI), fibrinogen alpha chain (FG), and urokinase plasminogen activator (PLAU), were significantly upregulated at $6 \mathrm{~h}$ and $24 \mathrm{~h}$, revealing the inhibition of blood coagulation, (Lin et al., 2011; Winslow et al., 2007). This may be related to the haemorrhagic septicaemia observed in yellow catfish caused by $E$. tarda infection. In summary, all these molecules were observed after E. tarda challenge, implying their potential roles in immune responses of yellow catfish (Table 4).

\section{Antigen Processing and Presentation}

Antigen processing refers to the antigen exposed to the surface of the presenting cells in the form of immune peptides by antigen presenting cell uptake, after which it is identified by the immunocompetent cells. This process, as the initial stage of the immune response, involves a variety of cellular mechanisms, including complement and coagulation cascades, apoptosis, and finally triggers the immune response. The two major classes of MHC molecules execute this function differently. For MHC class I molecules, the goal is to report on intracellular events (such as viral infection, the presence of intracellular bacteria or cellular transformation) to CD8+ T cells (Germain \& Margulies, 1993; Vyas et al., 2008). In MHC-I antigen processing and presentation pathway, MHC I, TAP binding protein (TAPBP), and beta-2-microglobulin ( $\beta 2 \mathrm{M})$ was upregulated at $6 \mathrm{~h}$. In addition, several important genes related to cytotoxic $T$ lymphocytes (CTL), including TNF $\alpha$, proteasome activator subunit 1 (PA28), HSP90, also showed varying degrees of up-regulation before 24h, further confirming the induction of CTL effector function. For MHC class II molecules, the goal is to sample the extracellular milieu and present antigens to CD4+ T cells4. In this study, MHC-II and CD4 showed a continuously down-regulated trend during the whole immunization phase. Therefore, we speculated that $E$. tarda might inhibit the function of MHC-II. Activated cytotoxic T lymphocytes released toxic particles such as perforin to kill host cells infected with E.tarda. This suggests that the antigen processing and presentation signaling pathway may serve as a bridge to communicate the complement and coagulation cascades and apoptosis signaling pathway and plays an essential role in fish early immune system (Table 4).

\section{Conclusion}

This study provided the first glimpse regarding the transcriptome of yellow catfish immune response upon E. tarda infection at three time points. A total of 158,124 unigenes were identified, including differentiallyexpressed genes related to immune responses, especially those in the antigen processing and presentation pathway, complement and coagulation cascades pathway, and apoptosis pathway. These pathways contribute to anti-bacterial responses after $E$. tarda challenge in yellow catfish. Overall, the data offers a platform to understand the molecular defense mechanisms underlying yellow catfish - E. tarda interactions, as well as to develop strategies for efficient immune protection against $E$. tarda infection to improve the yellow catfish aquaculture industry. 
Table 4. List of the differently expressed genes (DEGs) involved in immune responses.

\begin{tabular}{|c|c|c|c|c|c|c|c|}
\hline Gene name & Description & $\begin{array}{l}\text { Log2 } \\
\text { Fold }\end{array}$ & Diff & $\begin{array}{l}\text { Log2 } \\
\text { Fold }\end{array}$ & Diff & $\begin{array}{l}\text { Log2 } \\
\text { Fold }\end{array}$ & Diff \\
\hline \multicolumn{2}{|c|}{ Antigen processing and presentation } & \multicolumn{2}{|c|}{$6 \mathrm{~h}$} & \multicolumn{2}{|c|}{$24 \mathrm{~h}$} & \multicolumn{2}{|c|}{$72 \mathrm{~h}$} \\
\hline $\mathrm{TNF} \alpha$ & tumor necrosis factor alpha & 1.9 & up & - & - & - & - \\
\hline PA28 & proteasome activator subunit 1 (PA28 alpha) & 1.4 & up & 1.2 & up & - & - \\
\hline HSP9O & heat shock protein 90 & 1.8 & up & - & - & - & - \\
\hline CANX & calnexin & 1.5 & up & - & - & - & - \\
\hline MHC I & major histocompatibility complex, class I & 3.7 & up & 3.7 & up & - & - \\
\hline CALR & calreticulin & 1.3 & up & - & - & - & - \\
\hline$\beta 2 M$ & beta-2-microglobulin & 1.9 & up & - & - & - & - \\
\hline TAPBP & TAP binding protein (tapasin) & 1.6 & up & - & - & - & - \\
\hline TAP1/2 & $\begin{array}{l}\text { ATP-binding cassette, subfamily B } \\
\text { (MDR/TAP), member } 2\end{array}$ & 2.2 & up & 1.3 & up & - & - \\
\hline TCR & $\mathrm{T}$ cell receptor alpha chain $\mathrm{V}$ region & -2.4 & down & -4.3 & down & 4.3 & up \\
\hline AEP & legumain & 4.9 & up & - & - & - & - \\
\hline CTSB & cathepsin B & -1.8 & down & - & - & - & - \\
\hline MHC II & major histocompatibility complex, class II & -2.8 & down & -2.6 & down & -3.0 & down \\
\hline $\mathrm{CTSB} / \mathrm{L} / \mathrm{S}$ & cathepsin B & 6.7 & up & 3.9 & up & & \\
\hline CD4 & T-cell surface glycoprotein CD4 & -2.3 & down & -1.7 & down & - & - \\
\hline CIITA & $\begin{array}{l}\text { class II, major histocompatibility complex, } \\
\text { transactivator }\end{array}$ & -4.5 & down & - & - & - & - \\
\hline RFX & regulatory factor $\times 5$ & -2.0 & down & - & - & - & - \\
\hline li & CD74 antigen & - & - & -1.3 & down & - & - \\
\hline SLIP & CD74 antigen & - & - & -1.3 & down & - & - \\
\hline CLIP & CD74 antigen & - & - & -1.3 & down & - & - \\
\hline \multirow[t]{2}{*}{ NFY } & nuclear transcription factor $Y$, alpha & - & - & -4.8 & down & - & - \\
\hline & ement and coagulation cascades & \multicolumn{2}{|c|}{$6 \mathrm{~h}$} & \multicolumn{2}{|c|}{$24 \mathrm{~h}$} & \multicolumn{2}{|c|}{$72 \mathrm{~h}$} \\
\hline TFPI & tissue factor pathway inhibitor & 1.2 & up & 1.7 & up & - & - \\
\hline F3 & coagulation factor III (tissue factor) & 1.2 & up & - & - & - & - \\
\hline F7 & coagulation factor VII & -3.4 & down & - & - & - & - \\
\hline F10 & coagulation factor $X$ & 2.4 & up & 2.4 & up & 2.6 & up \\
\hline F8 & coagulation factor VIII & 8.4 & up & 5.0 & up & 3.5 & up \\
\hline FG & fibrinogen alpha chain & 5.8 & up & 3.6 & up & - & - \\
\hline $\mathrm{A} 2 \mathrm{M}$ & alpha-2-macroglobulin & -6.1 & down & -2.5 & down & -4.6 & down \\
\hline THBD & thrombomodulin & 1.3 & up & - & - & - & - \\
\hline SERPINE1 & plasminogen activator inhibitor 1 & 5.4 & up & 2.9 & up & 1.6 & up \\
\hline PLAU & urokinase plasminogen activator & 5.4 & up & 2.9 & up & 1.2 & up \\
\hline PLAUR & plasminogen activator, urokinase receptor & -3.1 & down & -2.6 & down & - & - \\
\hline PLG & plasminogen & -3.8 & down & - & - & - & - \\
\hline BDKR & bradykinin receptor $\mathrm{B} 1$ & 5.1 & up & 4.0 & up & 2.5 & up \\
\hline HF1 & complement factor $\mathrm{H}$ & 1.6 & up & 2.9 & up & 2.8 & up \\
\hline MCP & membrane cofactor protein & 4.0 & up & 4.1 & up & - & - \\
\hline CD59 & CD59 antigen & 6.3 & up & 4.7 & up & 4.1 & up \\
\hline C6 & complement component 6 & 2.4 & up & 2.5 & up & 1.6 & up \\
\hline $\mathrm{C7}$ & complement component 7 & 7.6 & up & 5.7 & up & 5.1 & up \\
\hline C1Q & complement component $1 q$ & -1.7 & down & 1.2 & up & - & - \\
\hline $\mathrm{C} 1 \mathrm{R}$ & complement C1r subcomponent & 2.0 & up & 2.4 & up & - & - \\
\hline C1S & complement component $1 \mathrm{~s}$ & 2.6 & up & - & - & - & - \\
\hline C4BP & $\begin{array}{l}\text { complement component } 4 \text { binding protein, } \\
\text { alpha }\end{array}$ & 3.6 & up & 3.5 & up & - & - \\
\hline C5R1 & C5a anaphylatoxin chemotactic receptor 1 & 2.3 & up & 2.2 & up & - & - \\
\hline CR1 & $\begin{array}{l}\text { complement component }(3 b / 4 b) \\
\text { receptor } 1\end{array}$ & 3.8 & up & 3.1 & up & - & - \\
\hline C3 & complement component 3 & - & - & 2.2 & up & 2.0 & up \\
\hline C4 & complement component 4 & - & - & 1.2 & up & - & - \\
\hline \multirow[t]{2}{*}{ DF } & component factor $\mathrm{D}$ & - & - & - & - & 1.9 & up \\
\hline & Apoptosis & \multicolumn{2}{|c|}{$6 \mathrm{~h}$} & \multicolumn{2}{|c|}{$24 \mathrm{~h}$} & \multicolumn{2}{|c|}{$72 \mathrm{~h}$} \\
\hline TRAIL & $\begin{array}{l}\text { tumor necrosis factor ligand superfamily } \\
\text { member } 10\end{array}$ & -1.6 & down & - & - & - & - \\
\hline TNF $\alpha$ & $\begin{array}{l}\text { tumor necrosis factor superfamily, member } \\
2\end{array}$ & 1.9 & up & - & - & - & - \\
\hline IL-1 & interleukin 1 alpha & 9.0 & up & 5.7 & up & 3.6 & up \\
\hline Fas & $\begin{array}{l}\text { tumor necrosis factor receptor superfamily } \\
\text { member } 6\end{array}$ & 2.2 & up & 1.2 & up & - & - \\
\hline
\end{tabular}


Table 4. List of the differently expressed genes (DEGs) involved in immune responses (continued).

\begin{tabular}{|c|c|c|c|c|c|c|c|}
\hline Gene name & Description & Log2 & $\begin{array}{l}\text { Gene } \\
\text { name }\end{array}$ & Description & $\log 2$ & $\begin{array}{l}\text { Gene } \\
\text { name }\end{array}$ & Description \\
\hline IL-1R & interleukin 1 receptor type I & 4.1 & up & 2.9 & up & 1.8 & up \\
\hline RIP1 & $\begin{array}{l}\text { receptor-interacting serine/threonine- } \\
\text { protein kinase } 1\end{array}$ & 1.1 & up & - & - & - & - \\
\hline TRAF2 & TNF receptor-associated factor 2 & 5.1 & up & 3.3 & up & 1.3 & up \\
\hline MyD88 & $\begin{array}{l}\text { myeloid differentiation primary } \\
\text { response protein MyD88 }\end{array}$ & 1.8 & up & - & - & - & - \\
\hline IRAK & $\begin{array}{l}\text { interleukin-1 receptor-associated kinase } \\
1\end{array}$ & 2.8 & up & 2.2 & up & - & - \\
\hline FLIP & $\begin{array}{l}\text { CASP8 and FADD-like apoptosis } \\
\text { regulator }\end{array}$ & 1.3 & up & - & - & - & - \\
\hline $\mathrm{Bcl}-2 / \mathrm{XL}$ & apoptosis regulator $\mathrm{Bcl}-2$ & 3.1 & up & - & - & - & - \\
\hline CASP10 & caspase 10 & 2.5 & up & - & - & - & - \\
\hline CASP8 & caspase 8 & -3.3 & down & - & - & - & - \\
\hline CASP3 & caspase 3 & 2.7 & up & 2.2 & up & - & - \\
\hline CASP7 & caspase 7 & 2.1 & up & 1.4 & up & - & - \\
\hline CASP6 & caspase 6 & 4.2 & up & 3.9 & up & 3.1 & up \\
\hline IAP & $\begin{array}{l}\text { baculoviral IAP repeat-containing } \\
\text { protein } 2 / 3\end{array}$ & 1.4 & up & - & - & - & - \\
\hline DFF40 & $\begin{array}{l}\text { DNA fragmentation factor, } 40 \mathrm{kD} \text {, beta } \\
\text { subunit }\end{array}$ & -1.7 & down & - & - & - & - \\
\hline AlF & apoptosis-inducing factor 1 & 1.7 & up & - & - & 2.2 & up \\
\hline Apaf-1 & apoptotic protease-activating factor & 1.2 & up & - & - & - & - \\
\hline IKK & $\begin{array}{l}\text { inhibitor of nuclear factor kappa-B } \\
\text { kinase subunit alpha }\end{array}$ & 1.1 & up & -5.0 & down & 1.2 & up \\
\hline IKB $\alpha$ & NF-kappa-B inhibitor alpha & 2.0 & up & - & - & - & - \\
\hline NF-KB & nuclear factor NF-kappa-B p105 subunit & 1.1 & up & - & - & - & - \\
\hline $\mathrm{Bcl}-\mathrm{XL}$ & Bcl-2-like 1 & 3.1 & up & - & - & - & - \\
\hline NGF & nerve growth factor, beta & 1.9 & up & 2.3 & up & - & - \\
\hline IL-3R & interleukin 3 receptor alpha & 3.5 & up & - & - & - & - \\
\hline PI3K & $\begin{array}{l}\text { phosphatidylinositol-4,5-bisphosphate } \\
\text { 3-kinase catalytic subunit }\end{array}$ & -3.5 & down & 2.0 & up & - & - \\
\hline PKA & protein kinase $A$ & -4.2 & down & -3.8 & down & - & - \\
\hline Bax & apoptosis regulator BAX & 2.1 & up & 1.6 & up & 1.1 & up \\
\hline p53 & tumor protein $\mathrm{p} 53$ & 3.3 & up & 2.5 & up & - & - \\
\hline Calpain & calpain-1 & 3.2 & up & - & - & - & \\
\hline TRAIL-R & $\begin{array}{l}\text { tumor necrosis factor receptor } \\
\text { superfamily member } 10 A / B\end{array}$ & -4.2 & down & - & - & - & - \\
\hline TNF-R1 & $\begin{array}{l}\text { tumor necrosis factor receptor } \\
\text { superfamily member } 1 \mathrm{~A}\end{array}$ & 2.6 & up & 2.3 & up & - & - \\
\hline IL-1R & interleukin 1 receptor type I & 4.1 & up & 2.9 & up & 1.8 & up \\
\hline RIP1 & $\begin{array}{l}\text { receptor-interacting } \\
\text { serine/threonine-protein kinase } 1\end{array}$ & 1.1 & up & - & - & - & - \\
\hline TRAF2 & TNF receptor-associated factor 2 & 5.1 & up & 3.3 & up & 1.3 & up \\
\hline MyD88 & $\begin{array}{l}\text { myeloid differentiation primary response } \\
\text { protein MyD88 }\end{array}$ & 1.8 & up & - & - & - & - \\
\hline IRAK & $\begin{array}{l}\text { interleukin-1 receptor-associated kinase } \\
1\end{array}$ & 2.8 & up & 2.2 & up & - & - \\
\hline FLIP & CASP8 and FADD-like apoptosis regulator & 1.3 & up & - & - & - & - \\
\hline $\mathrm{Bcl}-2 / \mathrm{XL}$ & apoptosis regulator $\mathrm{Bcl}-2$ & 3.1 & up & - & - & - & - \\
\hline CASP10 & caspase 10 & 2.5 & up & - & - & - & - \\
\hline CASP8 & caspase 8 & -3.3 & down & - & - & - & - \\
\hline CASP3 & caspase 3 & 2.7 & up & 2.2 & up & - & - \\
\hline CASP7 & caspase 7 & 2.1 & up & 1.4 & up & - & - \\
\hline CASP6 & caspase 6 & 4.2 & up & 3.9 & up & 3.1 & up \\
\hline IAP & $\begin{array}{l}\text { baculoviral IAP repeat-containing protein } \\
2 / 3\end{array}$ & 1.4 & up & - & - & - & - \\
\hline DFF40 & $\begin{array}{l}\text { DNA fragmentation factor, } 40 \mathrm{kD} \text {, beta } \\
\text { subunit }\end{array}$ & -1.7 & down & - & - & - & - \\
\hline AIF & apoptosis-inducing factor 1 & 1.7 & up & - & - & 2.2 & up \\
\hline Apaf-1 & apoptotic protease-activating factor & 1.2 & up & - & - & - & - \\
\hline
\end{tabular}


Table 4. List of the differently expressed genes (DEGs) involved in immune responses (continued).

\begin{tabular}{|c|c|c|c|c|c|c|c|}
\hline Gene name & Description & $\begin{array}{l}\text { Log2 } \\
\text { Fold } \\
\end{array}$ & Diff & $\begin{array}{l}\text { Log2 } \\
\text { Fold }\end{array}$ & Diff & $\begin{array}{l}\text { Log2 } \\
\text { Fold }\end{array}$ & Diff \\
\hline IKK & $\begin{array}{l}\text { inhibitor of nuclear factor kappa-B kinase } \\
\text { subunit alpha }\end{array}$ & 1.1 & up & -5.0 & down & 1.2 & up \\
\hline IкBa & NF-kappa-B inhibitor alpha & 2.0 & up & - & - & - & - \\
\hline NF-KB & nuclear factor NF-kappa-B p105 subunit & 1.1 & up & - & - & - & - \\
\hline $\mathrm{BCl}-\mathrm{XL}$ & Bcl-2-like 1 & 3.1 & up & - & - & - & - \\
\hline NGF & nerve growth factor, beta & 1.9 & up & 2.3 & up & - & - \\
\hline IL-3R & interleukin 3 receptor alpha & 3.5 & up & - & - & - & - \\
\hline PI3K & $\begin{array}{l}\text { phosphatidylinositol-4,5-bisphosphate } \\
\text { 3-kinase catalytic subunit }\end{array}$ & -3.5 & down & 2.0 & up & - & - \\
\hline PKA & protein kinase $A$ & -4.2 & down & -3.8 & down & - & - \\
\hline Bax & apoptosis regulator BAX & 2.1 & up & 1.6 & up & 1.1 & up \\
\hline p53 & tumor protein p53 & 3.3 & up & 2.5 & up & - & - \\
\hline Calpain & calpain-1 & 3.2 & up & - & - & - & \\
\hline
\end{tabular}

"-" represents the gene was not significantly different.

\section{Ethical Statement}

Animal experiments were carried out according to animal welfare standards and approved by the Ethical Committee for Animal Experiments of Foshan University. All animal experiments complied with the guidelines of the Animal Welfare Council of China.

\section{Funding Information}

This work was supported by Guangdong Natural Science Foundation (2017A030310642), the Guangdong Provincial Key Laboratory of Animal Molecular Design and Precise Breeding (2019B030301010), and the Key Laboratory of Animal Molecular Design and Precise Breeding of Guangdong Higher Education Institutes (2019KSYS011), R\&D projects in key areas of Guangdong Province (2019B110209005).

\section{Author Contribution}

Ying Yang and Jun Zhou finished the experiments and wrote the article. Hui $Y u$ gave the idea and experimental support. Pengfei Mao and Jiafang Xie provided assistance and guidance throughout the research. All authors assisted in writing the article and manuscript editing.

\section{Conflict of Interest}

The authors declare no conflicts of interest.

\section{Acknowledgements}

This work was supported by Guangdong Natural Science Foundation (2017A030310642), the Guangdong Provincial Key Laboratory of Animal Molecular Design and Precise Breeding (2019B030301010), and the Key Laboratory of Animal Molecular Design and Precise Breeding of Guangdong Higher Education Institutes (2019KSYS011), R\&D projects in key areas of Guangdong Province (2019B110209005).

\section{References}

Ahn, D. H., Kang, S., \& Park, H. (2016). Transcriptome analysis of immune response genes induced by pathogen agonists in the Antarctic bullhead notothen Notothenia coriiceps. Fish Shellfish Immunol, 55, 315-322. https://doi.org/10.1016/j.fsi.2016.06.004

Bang, J. D., Chun, S. K., Park, S. I., \& Choi, Y. J. (1992). Studies on the biochemical and serological characteristics of Edwardsiella tarda isolated from cultured flounder, Paralichthys olivaceus.

Chen, J., \& Chen, Z. J. (2013). Regulation of NF-kB by ubiquitination. Curr Opin Immunol, 25(1), 4-12. https://doi.org/10.1016/j.coi.2012.12.005

Chen, J., Xu, Y., Han, Q., Yao, Y., Xing, H., \& Teng, X. (2019). Immunosuppression, oxidative stress, and glycometabolism disorder caused by cadmium in common carp (Cyprinus carpio L.): Application of transcriptome analysis in risk assessment of environmental contaminant cadmium. Journal of Hazardous Materials, 366, 386-394. https://doi.org/10.1016/j.jhazmat.2018.12.014

Conesa, A., Götz, S., García-Gómez, J. M., Terol, J., Talón, M., \& Robles, M. (2005). Blast2GO: a universal tool for annotation, visualization and analysis in functional genomics research. Bioinformatics, 21(18), 3674-3676. https://doi.org/10.1093/bioinformatics/bti610

Dejardin, E. (2006). The alternative NF-kappaB pathway from biochemistry to biology: pitfalls and promises for future drug development. Biochem Pharmacol, 72(9), 11611179. https://doi.org/10.1016/j.bcp.2006.08.007

DiDonato, J. A., Hayakawa, M., Rothwarf, D. M., Zandi, E., \& Karin, M. (1997). A cytokine-responsive IkappaB kinase that activates the transcription factor NF-kappaB. Nature, 388(6642), 548-554. https://doi.org/10.1038/41493

Faherty, C. S., \& Maurelli, A. T. (2008). Staying alive: bacterial inhibition of apoptosis during infection. Trends in Microbiology, 16(4), 173-180. https://doi.org/10.1016/j.tim.2008.02.001

Fulda, S. (2009). Caspase-8 in cancer biology and therapy. Cancer Letters, 281(2), 128-133. https://doi.org/10.1016/j.canlet.2008.11.023

Fulda, S. (2009). Caspase-8 in cancer biology and therapy. Cancer Lett, 281(2), 128-133. https://doi.org/10.1016/j.canlet.2008.11.023 
Germain, R. N., \& Margulies, D. H. (1993). The biochemistry and cell biology of antigen processing and presentation. Annu Rev Immunol, 11, 403-450.

https://doi.org/10.1146/annurev.iy.11.040193.002155

Jia, Y. (2006). WEGO: a web tool for plotting GO annotations. Nucleic Acids Research, Web Server issue (34). https://doi.org/10.1093/nar/gkl031

Jiang, Y., Feng, S., Zhang, S., Liu, H., Feng, J., Mu, X., Sun, X., \& $\mathrm{Xu}, \mathrm{P}$. (2016). Transcriptome signatures in common carp spleen in response to Aeromonas hydrophila infection. Fish \& Shellfish Immunology, 57, 41-48.

https://doi.org/10.1016/j.fsi.2016.08.013

Langmead, B., \& Salzberg, S. L. (2012). Fast gapped-read alignment with Bowtie 2. Nature Methods, 9(4), 357 359.

https://doi.org/10.1038/nmeth.1923

Li, B., \& Dewey, C. N. (2011). RSEM: accurate transcript quantification from RNA-Seq data with or without a reference genome. BMC Bioinformatics, 12(1), 323. https://doi.org/10.1186/1471-2105-12-323

Li, Z., Liu, X. M., Liu, J. X., Zhang, K., Yu, H. Y., He, Y., Wang, X. B., Qi, J., Wang, Z. G., \& Zhang, Q. Q. (2018). Transcriptome profiling based on protein-protein interaction networks provides a core set of genes for understanding blood immune response mechanisms against \&ITEdwardsiella tarda\&IT infection in Japanese flounder (\&ITParalichthys olivaceus\&IT). Dev Comp Immunol, 78, 100-113. https://doi.org/10.1016/j.dci.2017.09.013

Lin, Y., Stanworth, S., Birchall, J., Doree, C., \& Hyde, C. (2011). Recombinant factor VIla for the prevention and treatment of bleeding in patients without haemophilia. Cochrane Database Syst Rev(2), Cd005011. https://doi.org/10.1002/14651858.CD005011.pub3

Liu, C., Yu, K., Shi, X., Wang, J., Lam, P. K. S., Wu, R. S. S., \& Zhou, B. (2007). Induction of oxidative stress and apoptosis by PFOS and PFOA in primary cultured hepatocytes of freshwater tilapia (Oreochromis niloticus). Aquatic Toxicology, 82(2), 135-143. https://doi.org/10.1016/j.aquatox.2007.02.006

Liu, H., Xie, J. F., Yu, H., Ma, Z., Yu, Y. Y., \& Yang, Y. (2021). The early response expression profiles of miRNA-mRNA in farmed yellow catfish (Pelteobagrus fulvidraco) challenged with Edwardsiella tarda infection. Dev Comp Immunol, 119, 104018. https://doi.org/10.1016/j.dci.2021.104018

Livak, K. J., \& Schmittgen, T. D. (2001). Analysis of relative gene expression data using real-time quantitative PCR and the 2(T)(-Delta Delta C) method. Methods, 25(4), 402-408. https://doi.org/10.1006/meth.2001.1262

Manfred G, G. (2011). Full-length transcriptome assembly from RNA-Seq data without a reference genome. Nature biotechnology, 7(29). https://doi.org/10.1038/nbt.1883

Markiewski, M. M., Nilsson, B., Ekdahl, K. N., Mollnes, T. E., \& Lambris, J. D. (2007). Complement and coagulation: strangers or partners in crime? Trends Immunol, 28(4), 184-192. https://doi.org/10.1016/j.it.2007.02.006

Meyer, F. P., \& Bullock, G. L. (1973). Edwardsiella tarda, a new pathogen of channel catfish (Ictalurus punctatus). Applied microbiology, 25(1), 155-156. https://doi.org/10.1128/am.25.1.155-156.1973

Mohanty, B. R., \& Sahoo, P. K. (2007). Edwardsiellosis in fish: a brief review. Journal of Biosciences, 32(3), 1331-1344. https://doi.org/10.1007/s12038-007-0143-8
Moriya, Y., Itoh, M., Okuda, S., Yoshizawa, A. C., \& Kanehisa, M. (2007). KAAS: an automatic genome annotation and pathway reconstruction server. Nucleic Acids Research, 35(suppl_2), W182-W185. https://doi.org/10.1093/nar/gkm321

Nakao, M., Tsujikura, M., Ichiki, S., Vo, T. K., \& Somamoto, T. (2011). The complement system in teleost fish: progress of post-homolog-hunting researches. Dev Comp Immunol, 35(12), 1296-1308. https://doi.org/10.1016/j.dci.2011.03.003

Nougayrede, P., Vuillaume, A., Vigneulle, M., Faivre, B., Luengo, S., \& Delprat, J. (1994). First isolation of Edwardsiella tarda from diseased turbot (Scophthalmus maximus) reared in a sea farm in the Bay of Biscay. Bulletin- European Association of Fish Pathologists, 14, 128-129.

Pålsson-McDermott, E. M., \& O'Neill, L. A. (2004). Signal transduction by the lipopolysaccharide receptor, Tolllike receptor-4. Immunology, 113(2), 153-162. https://doi.org/10.1111/j.1365-2567.2004.01976.x

Palta, S., Saroa, R., \& Palta, A. (2014). Overview of the coagulation system. Indian J Anaesth, 58(5), 515-523. https://doi.org/10.4103/0019-5049.144643

Pertea, G., Huang, X., Liang, F., Antonescu, V., Sultana, R., Karamycheva, S., Lee, Y., White, J., Cheung, F., Parvizi, B., Tsai, J., \& Quackenbush, J. (2003). TIGR Gene Indices clustering tools (TGICL): a software system for fast clustering of large EST datasets. Bioinformatics, 19(5), 651-652.

https://doi.org/10.1093/bioinformatics/btg034

Qi, G., Yu, N., Xu, K., Xie, X., Mao, Y., Chen, X., Ran, X., Chen, X., Lin, G., \& Hu, C. (2020). Grass carp (Ctenopharyngodon idella) Bcl-xl: transcriptional regulation and antiapoptosis analysis. Fish Physiol Biochem, 46(2), 483-500. https://doi.org/10.1007/s10695-019-00668-9

Raymond, B., Young, J. C., Pallett, M., Endres, R. G., Clements, A., \& Frankel, G. (2013). Subversion of trafficking, apoptosis, and innate immunity by type III secretion system effectors. Trends in Microbiology, 21(8), 430-439. https://doi.org/10.1016/j.tim.2013.06.008

Senftleben, U., Cao, Y., Xiao, G., Greten, F. R., Krähn, G., Bonizzi, G., Chen, Y., Hu, Y., Fong, A., Sun, S. C., \& Karin, M. (2001). Activation by IKKalpha of a second, evolutionary conserved, NF-kappa B signaling pathway. Science, 293(5534), 1495-1499. https://doi.org/10.1126/science.1062677

Sun, B., Li, X. P., Ning, X. H., \& Sun, L. (2020). Transcriptome Analysis of Paralichthys olivaceus Erythrocytes Reveals Profound Immune Responses Induced by Edwardsiella tarda Infection. International Journal of Molecular Sciences, 21(9), Article 3094. https://doi.org/10.3390/ijms21093094

Sun, S. C. (2017). The non-canonical NF-KB pathway in immunity and inflammation. Nat Rev Immunol, 17(9), 545-558. https://doi.org/10.1038/nri.2017.52

Tatusov, R. L., Fedorova, N. D., Jackson, J. D., Jacobs, A. R., Kiryutin, B., Koonin, E. V., Krylov, D. M., Mazumder, R., Mekhedov, S. L., Nikolskaya, A. N., Rao, B. S., Smirnov, S., Sverdlov, A. V., Vasudevan, S., Wolf, Y. I., Yin, J. J., \& Natale, D. A. (2003). The COG database: an updated version includes eukaryotes. BMC Bioinformatics, 4(1), 41. https://doi.org/10.1186/1471-2105-4-41

Vallabhapurapu, S., \& Karin, M. (2009). Regulation and function of NF-kappaB transcription factors in the immune system. Annu Rev Immunol, 27, 693-733. 
https://doi.org/10.1146/annurev.immunol.021908.132 641

Vyas, J. M., Van der Veen, A. G., \& Ploegh, H. L. (2008). The known unknowns of antigen processing and presentation. Nat Rev Immunol, 8(8), 607-618. https://doi.org/10.1038/nri2368

Winslow, Ron, Johnson, \& Avery. (2007). Race Is on for the Next Blood Thinner. Wall Street Journal Eastern Edition.

Yang, Y., Miao, P., Liu, H., Du, Y., Tan, S., \& Yu, H. (2019). Expression and immunofluorescent localization of the Edwardsiella tarda EvpC protein in infected Pelteobagrus fulvidraco. Aquaculture, 511, 634201. https://doi.org/10.1016/j.aquaculture.2019.06.015

Yang, Y., Yu, H., Li, H., \& Wang, A. (2016). Transcriptome profiling of grass carp (Ctenopharyngodon idellus) infected with Aeromonas hydrophila. Fish \& Shellfish Immunology, 51, 329-336.

https://doi.org/10.1016/j.fsi.2016.02.035

Yasunaga, N., Ogawa, S., \& Hatai, K. (1982). Characteristics of the fish pathogen Edwardsiella isolated from several species of cultured marine fishes. Bull. Nagasaki Prefect. Inst. Fish. Jpn.
Ye, J., Fang, L., Zheng, H., Zhang, Y., Chen, J., Zhang, Z., Wang, J., Li, S., Li, R., Bolund, L., \& Wang, J. (2006). WEGO: a web tool for plotting $\mathrm{GO}$ annotations. Nucleic Acids Research, 34(suppl_2), W293-W297. https://doi.org/10.1093/nar/gkl031

Zhou, Z.-j., \& Sun, L. (2016). Edwardsiella tarda-Induced Inhibition of Apoptosis: A Strategy for Intracellular Survival. Frontiers in Cellular and Infection Microbiology, 6, Article 76. https://doi.org/10.3389/fcimb.2016.00076

Zhou, Z.-j., \& Sun, L. (2016). Edwardsiella tarda-Induced Inhibition of Apoptosis: A Strategy for Intracellular Survival. Frontiers in Cellular and Infection Microbiology, 6, Article 76. https://doi.org/10.3389/fcimb.2016.00076

Zoccola, E., Kellie, S., \& Barnes, A. C. (2017). Immune transcriptome reveals the mincle C-type lectin receptor acts as a partial replacement for TLR4 in lipopolysaccharide-mediated inflammatory response in barramundi (Lates calcarifer). Mol Immunol, 83, 33-45. https://doi.org/10.1016/j.molimm.2017.01.010 